\title{
EXPERIMENTAL INVESTIGATION OF MECHANICAL PROPERTIES OF
}

\section{SAW WELDMENTS OF IS-2062 STEEL PLATES}

\author{
MEENU SHARMA $^{1} \&$ SHAHNWAZ ALAM ${ }^{2}$ \\ ${ }^{I}$ Research Scholar, Department of Mechanical Engineering, Integral University, Lucknow, India \\ ${ }^{2}$ Associate Professor, Department of Mechanical Engineering, Integral University, Lucknow, India
}

\section{ABSTRACT}

A study was undertaken to analyze Submerged Arc welding (SAW) of IS-2062 Steel plates keeping in mind the potential capabilities of SAW welding process and selecting IS-2062 Steel Plates as the base metal due to its vide applications in railway industries. Primary welding parameters, viz. welding current, arc voltage, welding speed and nozzle to plate distance were identified and investigations were carried out to study their effect on the weld strength of the weldments by using factorial design. A brief introduction to the SAW welding processes is included, along with the literature review of the research in the field of $S A W$ welding of alloy steels.

KEY WORDS: IS-2062 Steel, Submerged Arc Welding, Weld Strength \& ANNOVA

Received: Apr 18, 2018; Accepted: May 05, 2018; Published: Aug 11, 2018; Paper Id: IJMPERDAUG2018108

\section{INTRODUCTION}

Mechanical properties of submerged Arc welds determine the quality and life of welded joints. Properties which determine quality of weld are mainly the depth of penetration in welding and the weld strength. Predicting the values of the process parameters on which desired weld quality depends is a very complex process and so many investigators have tried to investigate the process parameters to obtain high quality welds. Present investigation carried for welding IS-2062 steel plates using submerged arc welding process.

Table 1: IS: 2062-Chemical Composition and Specification of Steel for General Structural Purposes

\begin{tabular}{|c|c|c|c|c|c|}
\hline C\% Max. & Mn \% Max. & S\% Max. & P\% Max. & Si \% Max. & C.E. \% Max. \\
\hline 0.23 & 1.50 & 0.050 & 0.050 & 0.40 & 0.42 \\
\hline
\end{tabular}

\section{EXPERIMENTATION PLANNING}

This study details with an experimental work on IS 2062 steel using SAW process to yield desired quality of bead, in terms of beads geometry, as influenced by voltage, current, welding speed and nozzle to-plate distance which are varied in five different levels. The desired welding parameters are determined based on the standard practice as obtained from literature review. The welding equipment used has the following specifications: welding rod diameter of $3.2 \mathrm{~mm}$ and composition C: $0.10 \%$; Mn: 0.4-0.6\%; Si: $0.03 \%$; S: $0.03 \%$; P: $0.03 \%$; Cu: $0.4 \%$ the weight of copper includes copper coating too. The work piece was in a rectangular shaped plate made of steel alloy grade - IS: 2062 having the dimensions of 300*150*20 mm in size with chemical composition: C 0.23\%; Mn: 1.50 5; S: $.050 \%$; P: $0.050 \%$; Si: $0.40 \%$; C.E: $0.42 \%$ and remaining iron. The joint was in bead shape on welded junction of plates. Taguchi approach has been carried out for investigation, as from literature review, it was 
observed that this technique is used extensively for solving optimization problems in the field of production engineering.

Table 2: Parameters and their Values

\begin{tabular}{|c|c|c|c|c|c|c|c|c|}
\hline \multirow{2}{*}{$\begin{array}{l}\mathrm{Sr} \\
\text { No }\end{array}$} & \multirow{2}{*}{ Symbol } & \multirow{2}{*}{ Parameters } & \multicolumn{5}{|c|}{ Levels } & \multirow{2}{*}{ Units } \\
\hline & & & I & II & III & IV & $\mathbf{V}$ & \\
\hline 1 & $\mathrm{~A}$ & Arc voltage & 24 & 26 & 28 & 30 & 32 & volts \\
\hline 2 & $\mathrm{~B}$ & Welding Current & 375 & 425 & 475 & 525 & 575 & amperes \\
\hline 3 & $\mathrm{C}$ & Trolley speed & 0.25 & 0.30 & 0.35 & 0.40 & 0.45 & $\mathrm{~m} / \mathrm{min}$ \\
\hline 4 & $\mathrm{D}$ & Nozzle to plate distance & 15 & 16 & 17 & 18 & 19 & $\mathrm{~mm}$ \\
\hline
\end{tabular}

The experiments were carried out and samples obtained were tested for penetration and weld strength. Further, to determine the significance of factors on the responses, analysis of variance (ANOVA) has been used. Table 2 presents selected parameters with their actual values.

\section{RESULTS}

Table 3 presents experimentation planning using L-25 $\left(5^{4}\right)$ orthogonal array. The experimental results of weld strength and bead penetration are plotted in the Figure 1.

Table 3: Experimentation Planning using L-25 (5 $\left.{ }^{4}\right)$ Orthogonal Array

\begin{tabular}{|c|c|c|c|c|c|c|c|c|c|}
\hline \multirow{2}{*}{$\begin{array}{l}\text { Exp. } \\
\text { No. }\end{array}$} & \multicolumn{4}{|c|}{$\begin{array}{l}\text { Coded values using L-25 } \\
\left(5^{4}\right) \text { orthogonal array }\end{array}$} & \multicolumn{4}{|c|}{$\begin{array}{l}\text { Actual values using L-25 } \\
\left(5^{4}\right) \text { orthogonal array }\end{array}$} & \multirow{2}{*}{$\begin{array}{c}\text { Raw output } \\
\text { obtained }\end{array}$} \\
\hline & $\begin{array}{c}\mathbf{A} \\
(\mathbf{1})\end{array}$ & $\begin{array}{c}\text { B } \\
(2)\end{array}$ & $\begin{array}{c}\mathrm{C} \\
(3)\end{array}$ & $\begin{array}{c}D \\
(4)\end{array}$ & $\mathbf{A}$ & B & $\mathbf{C}$ & D & \\
\hline 1 & 1 & 1 & 1 & 1 & 24 & 375 & 0.25 & 15 & 427.61 \\
\hline 2 & 1 & 2 & 2 & 2 & 24 & 425 & 0.30 & 16 & 462.08 \\
\hline 3 & 1 & 3 & 3 & 3 & 24 & 475 & 0.35 & 17 & 487.36 \\
\hline 4 & 1 & 4 & 4 & 4 & 24 & 525 & 0.40 & 18 & 505.00 \\
\hline 5 & 1 & 5 & 5 & 5 & 24 & 575 & 0.45 & 19 & 520.23 \\
\hline 6 & 2 & 1 & 2 & 3 & 26 & 375 & 0.30 & 17 & 545.29 \\
\hline 7 & 2 & 2 & 3 & 4 & 26 & 425 & 0.35 & 18 & 565.25 \\
\hline 8 & 2 & 3 & 4 & 5 & 26 & 475 & 0.40 & 19 & 638.45 \\
\hline 9 & 2 & 4 & 5 & 1 & 26 & 525 & 0.45 & 15 & 610.07 \\
\hline 10 & 2 & 5 & 1 & 2 & 26 & 575 & 0.25 & 16 & 637.21 \\
\hline 11 & 3 & 1 & 3 & 5 & 28 & 375 & 0.35 & 19 & 562.39 \\
\hline 12 & 3 & 2 & 4 & 1 & 28 & 425 & 0.40 & 15 & 601.34 \\
\hline 13 & 3 & 3 & 5 & 2 & 28 & 475 & 0.45 & 16 & 618.64 \\
\hline 14 & 3 & 4 & 1 & 3 & 28 & 525 & 0.25 & 17 & 538.49 \\
\hline 15 & 3 & 5 & 2 & 4 & 28 & 575 & 0.30 & 18 & 589.26 \\
\hline 16 & 4 & 1 & 4 & 2 & 30 & 375 & 0.40 & 16 & 368.45 \\
\hline 17 & 4 & 2 & 5 & 3 & 30 & 425 & 0.45 & 17 & 345.74 \\
\hline 18 & 4 & 3 & 1 & 4 & 30 & 475 & 0.25 & 18 & 354.85 \\
\hline 19 & 4 & 4 & 2 & 5 & 30 & 525 & 0.30 & 19 & 348.56 \\
\hline 20 & 4 & 5 & 3 & 1 & 30 & 575 & 0.35 & 15 & 341.94 \\
\hline 21 & 5 & 1 & 5 & 4 & 32 & 375 & 0.45 & 18 & 322.65 \\
\hline 22 & 5 & 2 & 1 & 5 & 32 & 425 & 0.25 & 19 & 365.45 \\
\hline 23 & 5 & 3 & 2 & 1 & 32 & 475 & 0.30 & 15 & 401.33 \\
\hline 24 & 5 & 4 & 3 & 2 & 32 & 525 & 0.35 & 16 & 325.18 \\
\hline 25 & 5 & 5 & 4 & 3 & 32 & 575 & 0.40 & 17 & 318.46 \\
\hline
\end{tabular}



Saw Weldments of IS-2062 Steel Plates

Figure 1 here shows the main effects of the plots has been generated using Minitab software. The results obtained have been plotted and shows how, each factor like Arc voltage, Welding Current, Trolley speed and Nozzle to plate distance affects the response characteristic ie. Weld strength.

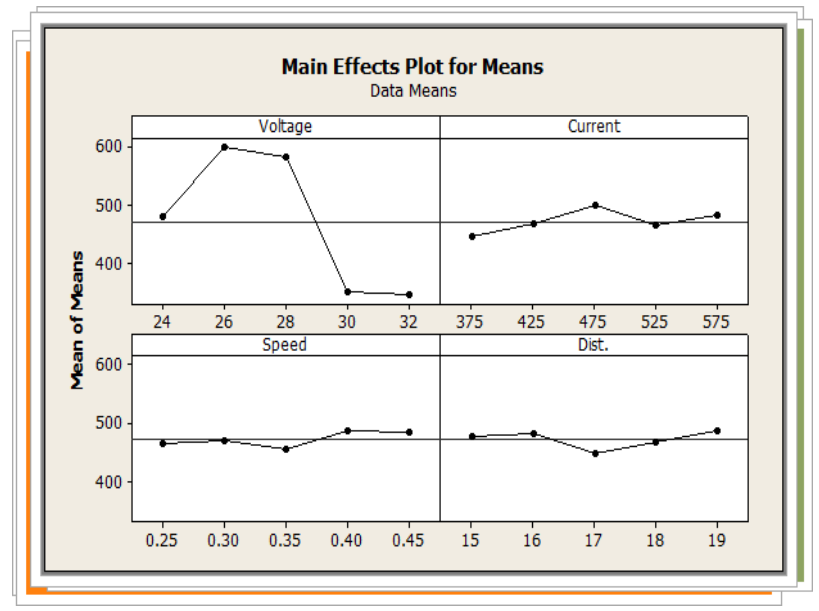

Figure 1: Plot of Mean for Ultimate Tensile

Analysis of variance (ANOVA) was performed to identify the process parameters which significantly affect the weld strength. The ANOVA for the raw data is shown in the Figure 2.

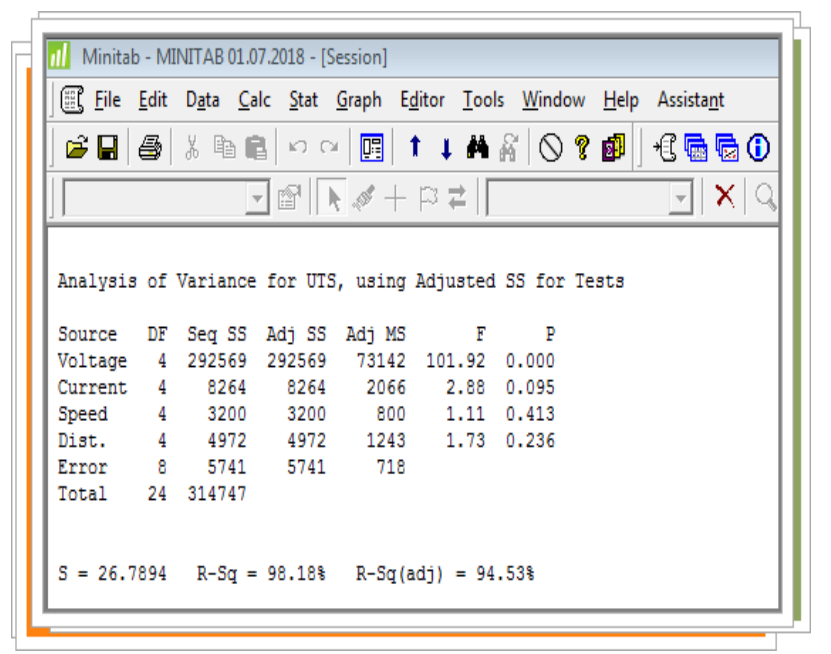

Figure 2: ANNOVA Table for Experimental Observations

Figure 3 shows that the plots exhibit pretty symmetrically distribution and thus reflect a linear regression model of the raw data. 


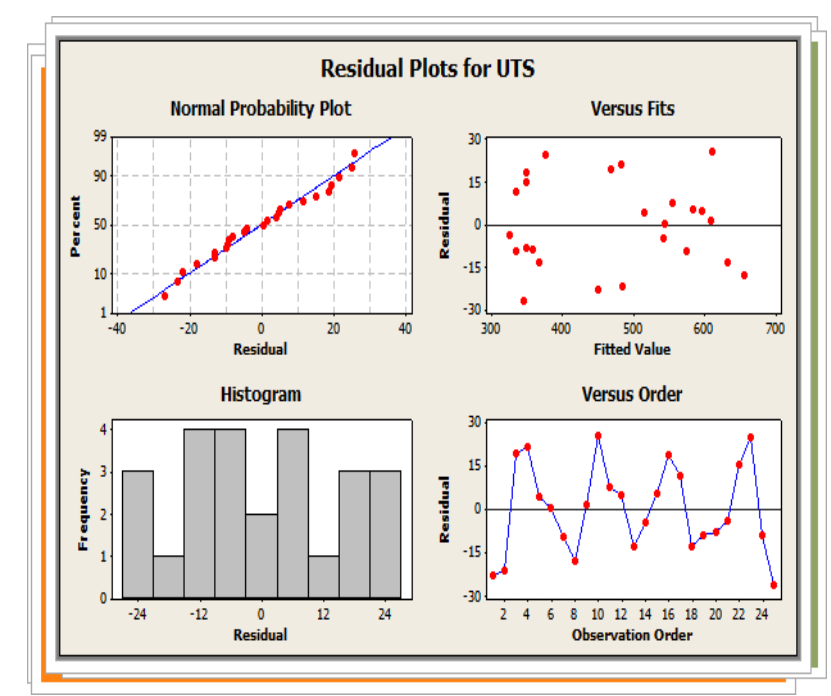

Figure 3: Residual Plots for UTS

\section{CONCLUSIONS}

The results of the present investigation indicate that the welding voltage is the most significant parameter that controls the bead penetration as compared to other controlling parameters. The contribution of voltage is found to be quite significant, while the current welding speed and nozzle-to-plate distance have been found to be less significant. Optimal values of the process parameters obtained are voltage $26 \mathrm{~V}$, Current $475 \mathrm{~A}$, trolley speed of $0.40 \mathrm{~m} / \mathrm{min}$ and NPD of $19 \mathrm{~mm}$. Very higher arc voltage results in flattering of beads thus dilution which further causes porosity defects. Thus optimum voltage is required to reduce defects and for proper bead penetration leading to better strength.

\section{ACKNOWLEDGEMENT}

The authors would like to thank the Research Design and Standards Organisation (RDSO), Lucknow for the support to undergo the experimental work.

\section{REFERENCES}

1. Dhollander, R., Vancauwenberghe, S., De Waele, W., Van Caenegem, N., \& Van Pottelberg, E. (2012). Multiwire submerged arc welding of steel structures. In Sustainable Construction and Design(Vol. 3, No. 3, pp. 228-233). Ghent University, Laboratory Soete.

2. Singh, R. P., Garg, R. K., \& Shukla, D. K. (2012). Parametric Effect on Mechanical Properties in Submerged arc welding process-A review. International Journal of Engineering Science and Technology, 4(2), 11.

3. Chandel, R. S., Seow, H. P., \& Cheong, F. L. (1997). Effect of increasing deposition rate on the bead geometry of submerged arc welds. Journal of Materials Processing Technology, 72(1), 124-128.

4. Pandey, A. K., Khan, M. I., \& Moeed, K. M. (2013). Investigation of the effect of current on tensile strength and nugget diameter of spot welds made on AISI-1008 steel sheets. Int J Tech Res Appl, 1(8).

5. Kanda, R., Akhai, S., \& Bansal, R. (2013). Analysis of MOST technique for elimination of ideal time by synchronization of different lines. International Journal, 1(4).

6. Singh, G., \& Akhai, S. (2015). Experimental study and optimisation of MRR in CNC plasma arc cutting. International Journal of Engineering Research and Applications, 5(6), 96-99. 


\section{Saw Weldments of IS-2062 Steel Plates}

7. Kumar, A. P., \& Krishna, C. S. R. Sensitivity Analysis Of Tig Welding Parameters For Astm-500 Grade B Weldments.

8. Choudhary, D. K., Jindal, S., \& Mehta, N. P. (2011). To study the effect of welding parameters on weld bead geometry in SAW welding process. Elixir Mechanical Engineering Journal, 40, 5519-5524.

9. Murugan, N., Parmar, R. S., \& Sud, S. K. (1993). Effect of submerged arc process variables on dilution and bead geometry in single wire surfacing. Journal of Materials Processing Technology, 37(1-4), 767-780.

10. Srivastava, S., \& Garg, R. K. (2017). Process parameter optimization of gas metal arc welding on IS: 2062 mild steel using response surface methodology. Journal of Manufacturing Processes, 25, 296-305.

11. Prasad, K., \& Dwivedi, D. K. (2008). Some investigations on microstructure and mechanical properties of submerged arc welded HSLA steel joints. The international journal of advanced manufacturing technology, 36(5-6), 475-483. 
